\title{
Doprinos melografa Miroslava Vuka Croate (1930-2005) hrvatskoj tradicijskoj glazbenoj kulturi
}

Katarina Koprek*

katarinakoprek@hotmail.com
UDK: 78 Vuk Croata, $M$. 39:78(436.3=163.42 + 497.5)

Pregledni članak / Review Primljeno: 2. siječnja 2018. Prihvaćeno: 22. veljače 2018.

U niz hrvatskih etnomuzikologa 20. stoljeća ubraja se i Miroslav Vuk Croatasakupljač glazbenoga blaga hrvatske sakralne i svjetovne popijevke. Kao mlad suradnik poznatoga etnomuzikologa Vinka Z̆ganca, nastavio je njegovo djelo: od zaborava je sačuvao znatan dio duhovne tradicijske glazbene baštine - kako u Hrvatskoj tako i u zemljama gdje žive Hrvati (Austrija, Madarska, Slovačka i Moravska) - prikupljajući, zapisujući i tonski snimajući, pučke crkvene i svjetovne popijevke. Prikupljeni je materijal uredio i za života objavio. Etnomuzikološka darovitost Vuka Croate došla je do izražaja i u glazbenim obradama pučkih popijevaka za razne zborove duhovnoga i svjetovnoga sadržaja. Posebno je vrijedan njegov doprinos istraživanjima narodnih, svjetovnih $i$ crkvenih popjevaka (jački) Hrvata iz Gradišća. Već iz samih naslova popijevki uočavaju se osobitosti mjesnoga govora. U njegovim glazbenim zbirkama (pjesmaricama) potvrduje se nedvojbena motivska i glazbena povezanost većega broja popijevaka sa srodnim popijevkama u domovini, kao što se otkrivaju i neke tematske i glazbene posebnosti nove sredine u kojoj žive Hrvati, čuvajući svojim starim jezikom popijevku, a popijevkom jezik, odnosno jednim i drugim svoj nacionalni identitet.

Ključne riječi: hrvatska etnomuzikologija, kroatologija, kajkavska narodna baština, pučke svjetovne i crkvene popijevke, jezik i kultura gradišćanskih Hrvata.

\footnotetext{
* Izv. prof. dr. sc. Katarina Koprek, Katolički bogoslovni fakultet Sveučilišta u Zagrebu, Vlaška 38, pp 432, HR-10001 Zagreb.
} 


\section{Uvod}

Svako vrijeme i svaki narod obdareni su kulturnim, znanstvenim i inim velikanima. Oni su nam svojevrstan izazov. Zato je takvima potrebno dati posebno mjesto u sadašnjemu trenutku i iznova podsjetiti na jedinstvenu ulogu na području njihova djelovanja. Jedan od takovih bio je i međimurski etnomuzikolog, muzikolog, pjesnik, pisac, slikar, glazbenik, skladatelj, profesor glazbe, zborovođa, školnik i kantor, sakupljač glazbenoga blaga hrvatske sakralne i svjetovne popijevke Miroslav Vuk Croata. Kao marljiv sakupljač i tumač hrvatske kulturno-glazbene baštine svoju je ljubav prema Hrvatskoj posvjedočio dodavanjem naziva Croata svome prezimenu. $\mathrm{U}$ autobiografskim bilješkama ${ }^{1}$ je zapisao:

»Odlučio sam dio svoje mladosti, a kasnije i života posvetiti prikupljanju svega lijepoga u umjetnosti i znanosti gdje se spominje i veliča hrvatsko ime, čuvajući prošlost za sadašnjost i budućnost. ${ }^{2}$

Ponekad se ovaj sin hrvatskoga Međimurja potpisivao »Canis Lupo Lupus Pacificus Magnus Croata et Insulanus z varaša seh Horvatov Zagreba« pa su ga stoga prijatelji u pismima često oslovljavali: »Bonus Musicus Lupo Canis Lupus Pacificus Magnus Croata«. Akademik Lovro Županović spominje ga pišući o međimurskim glazbenicima:

»Budu li se ikada u kontekstu razmatranja razvitka hrvatske glazbene kulture 20. stoljeća tekstovno opširnije opisivali prinosi regija zemlje Hrvatske, onda će u udarnoj falangi međimurske regije valjati navesti imena najprije tandema Vinka Žganca i Josipa Štolcera Slavenskoga - predvođenih nezaobilaznim Florijanom Andrašecom - potom četverolist što ga tvore Josip Vrhovski, Miroslav Magdalenić, Mirko Kolarić i Joža Požgaj, te (nakon duže stanke) začelnik Miroslav Vuk, rođenjem (zasad) posljednji hvalevrijedni glazbeni poslenik spomenute regije. « ${ }^{3}$

O njegovu spomenutom djelovanju svjedoče objelodanjene pjesmarice, mnogobrojni svesci sabranih narodnih, svjetovnih i crkvenih popjevaka, knjige o međimurskim kantorima, harmonizacije i veliko muzikološko blago koje je tijekom života ljubomorno prikupljao i još ljubomornije čuvao za budućnost. ${ }^{4}$

\footnotetext{
${ }^{1}$ Pisana ostavština Miroslava Vuka Croate (u daljnjem tekstu kratica za autora MVC) nalazi se u knjižnici Katoličkoga bogoslovnog fakulteta Sveučilišta u Zagrebu (dalje: KKBF), na Šalati, Voćarska 106 u Zagrebu, dosad, nažalost, nekatalogizirana. Materijali su pohranjeni u tri fascikla: Fascikl - Autobiografija (dalje: KKBF: fasc. - MVC Autobiografija), Fascikl Korespondencija (dalje: KKBF: fasc. - MVC Korespondencija), Fascikl - Znanstveni skupovi (dalje: KKBF: fasc. MVC Znanstveni skupovi).

2 KKBF: fasc. - MVC Autobiografija.

${ }^{3}$ Usp. Lovro ŽUPANOVIĆ, Mirko Kolarić, glazbenik maćuhinske sudbine. Uz 85. obljetnicu njegova rođenja i 50. obljetnicu njegove nasilne smrti, Hrvatsko slovo, 23. lipnja 1995., 21-22; usp. Stjepan RAZUM, Miroslav Vuk Croata (1930.-2005.), glazbeni odgojitelj i etnomuzikolog, Tkalčić, 9 (2005) 451-578, 558.

${ }^{4}$ Opširne biografske podatke u godini smrti Miroslava Vuka Croate napisao je dr. Stjepan Razum u časopisu Tkalčić. Časopis izlazi od 1997. godine u izdanju »Društva za povjesnicu
} 


\section{Oris životopisa i djelovanja Miroslava Vuka Croate}

Miroslav Vuk Croata rodio se 18. svibnja 1930. godine u Mačkovcu, pokraj Čakovca. Tu je polazio osnovnu školu do 1941. godine dijelom hrvatsku, a za vrijeme Drugoga svjetskoga rata dijelom mađarsku. U Čakovcu je pohađao i glazbenu školu, dok je istodobno orguljao u mjesnoj crkvi. Upravo ta činjenica bila je razlogom da su ga tadašnji politički moćnici izbacili iz škole i uhitili. Kao dvadesetogodišnji mladić bio je 1950. godine poslan na prisilni rad, u sječu šume pokraj Mrkoplja. Od daljnjih se neugodnosti političkih progona spasio bijegom u Sloveniju, gdje je nekoliko godina radio kao zidarski radnik. Povratkom u Hrvatsku nastavio je glazbenu izobrazbu kod profesora Miroslava Magdalenića posebnički učiti harmoniju, kontrapunkt i glasovir. Uz njegovu se pomoć upisao na Državnu muzičku školu, a 1962. godine i na Muzičku akademiju u Zagrebu. Uz školovanje je orguljao i vodio dva mješovita zbora u župnoj crkvi sv. Jeronima u Zagrebu (Maksimir). Već je 1954. godine postao suradnik Vinka Žganca, najznačajnijega hrvatskog sakupljača narodnoga glazbenoga blaga u 20. stoljeću, a od 1960. godine i njegov osobni tajnik. ${ }^{5} \mathrm{U}$ tom je svojstvu uredio Žgančevu bogatu glazbenu ostavštinu. Osim toga, zajedno je sa Žgancem pripremio za tiskanje zbirku Franje Kuhača »Južnoslovjenske narodne popievke« (VI. knjiga, 1975-1976). ${ }^{6}$ Za tisak je uredio pjesmaricu Žgančevih zapisa »Crkvene popijevke iz Bačke« (1977) i pjesmaricu »Narodne popijevke iz Sombora i okolice« (1979).

Cijeli svoj radni vijek Miroslav Vuk Croata proveo je kao glazbeni odgojitelj u osnovnoj školi »Kustošija«, odnosno »Ivana Brlić Mažuranić« u Zagrebu. No, rad u školi nije iscrpio sve njegove snage. Tako se, uz odgojni rad, bavio i glazbenom teorijom, surađujući s Josipom Završkim na programima i glazbenim priručnicima.

Melografsko bilježenje »starinskih svetih popefki« Vuk Croata započeo je na savjet svoga profesora Magdalenića, a poslije i Žganca, najprije u rodnome domu (selu Mačkovcu), potom i u svim selima »čakofske fare«. Potom ga je proširio na Međimurje i na sva područja gdje žive Hrvati (Austrija, Mađarska, Slovačka, SAD, Kanada....).

Tragajući za starim, često rukopisnim, pjesmaricama i kantualima, zapisujući i tonski snimajući pučke crkvene i svjetovne popijevke, Vuk Croata je

Zagrebačke nadbiskupije«. Miroslov Vuk Croata bio je član osnivačkoga odbora toga društva koje je osnovano prigodom 900. obljetnice Zagrebačke nadbiskupije, a osnivačka je skupština održana 23. svibnja 1996. godine u Zagrebu. Časopis Tkalčić objavljuje radove o prošlosti Zagrebačke nadbiskupije iz različitih područja ljudske djelatnosti (usp. Razum, Miroslav Vuk Croata..., 573).

${ }^{5}$ Usp. Miroslav VUK (ur.), Hrvatske crkvene i svjetovne popijevke Florijana Andrašeca, kantora u Dekanovcu u Međimurju, 2. prošireno i izmijenjeno izd., Zagreb [s. n.], 2002, 6.

${ }^{6}$ Ova zbirka pjesama još nije tiskana! 
prikupio obilje materijala. ${ }^{7}$ Sve sakupljeno za života je uredio i objavio u devet knjiga - pjesmarica: »Hrvatska crkvena pjesmarica za Hrvate u Kanadi« (Toronto, 1989), »Jačke gradišćanskih Hrvata u Mađarskoj« (Izdanje Saveza Hrvata u Mađarskoj, Budimpešta, 1991), »Hrvatske narodne popijevke i plesovi iz Draganića i okolice« (Draganići: KUD Sv. Juraj, 1994), »Hrvatske božićnice« (HKD sv. Jeronima Zagreb, 1995), »Hrvatske romarske popijevke« (HKD sv. Jeronima Zagreb, 1996), »Hrvatske uskrsnice« (»Dr. Feletar« Zagreb, 1998), »Skladbe i život Ivana Mustača, kantora u Svetoj Mariji u Međimurju« (Sveta Marija, 2001), »Hrvatske crkvene i svjetovne popijevke Florijana Andrašeca, kantora u Dekanovcu u Međimurju « (Zagreb, 2002) i posljednja pjesmarica »Hrvatske romarske popijevke $«^{8}$ - njezino drugo i prošireno izdanje ostalo je u rukopisu, a pred smrt je bio dogovarao tiskanje s izdavačkom kućom »Glas Koncila«. U pismu 20. listopada 2002. Petru Tyranu piše: ${ }^{9}$

»Sada sam pred završetkom drugoga izdanja (proširenoga) hrvatskih romarskih popijevaka. Međutim kad su u Institutu za crkvenu glazbu vidjeli materijal, naprosto su me prisilili da u pjesmaricu stavim i sve Marijine patronske popijevke koje se pjevaju kao himne u pojedinim Marijinim svetištima gdje živi ili hodočasti hrvatski narod. Eto iz Jura sam dobio, iz Koljnofa imam jer mi je riječi ispjevao vlč. Anton Slavić, a ja sam uglazbio. Međutim nemam od Celjske Marije, jačku koja se smatra - kako bi se reklo - službena himna ili svečana pjesma u čast Majke Božje Celjske.«10

Svoj rad Vuk Croata je programatski opisivao u predgovorima svojih pjesmarica. Tako u predgovoru pjesmarice »Hrvatske božićnice« piše:

»Na bilježenje napjeva i tekstova prisilila me potreba sada već daleke 1945. godine, otkad sam, do 1950., bio zborovođa i orguljaš u župnoj crkvi sv. Nikole, u Čakovcu. Budući da sam za vrijeme rata polazio mađarsku školu, nisam znao starih 'horvackih cirkvenih popevki' koje su u crkvi vjernici željeli pjevati i slušati. Tako sam započeo bilježenjem starih popijevaka.«111

Plod njegova terenskoga rada, bilježenja i harmonizacije hrvatskih pučkih popijevaka također su znanstveni i istraživački radovi pretežito etnomuzikološke tematike. Njegove znanstvene i popularne članke nalazimo u raznim časopisima, novinama i kalendarima u Hrvatskoj, Mađarskoj i Austriji. Najviše je pisao o međimurskim orguljašima, pjevačima, glazbenim odgojiteljima, muzikolozima i skladateljima (F. Kuhač, V. Žganec, M. Magdalenić, H. Pettan, T.

\footnotetext{
7 Usp. M. VUK, Hrvatske uskrsnice, Zagreb, Naklada »Dr. Feletar«, 1998, V.

${ }^{8}$ Romar ili hodočasnik - riječ je o hrvatskim hodočasničkim pjesmama.

9 Petar Tyran je hrvatski književnik, društveni djelatnik, publicist i aktivist iz Gradišća. U Beču je studirao anglistiku, filozofiju i slavistiku.

${ }^{10} \mathrm{KKBF}$ : fasc. - MVC Korespondencija.

${ }^{11}$ M. VUK, Hrvatske božićnice, Zagreb, HKD Sv. Jeronima, 1995, III; Vuk, Hrvatske uskrsnice..., $\mathrm{V}$.
} 
Adamić, B. Prister, A. Forster, F. Andrašec, I. Mustač, te mučki ubijeni i dugo prešućivani skladatelj Mirko Kolarić). ${ }^{12}$

Vuk Croata često je sudjelovao na znanstvenim i stručnim simpozijima. Od 1960. godine održao je više od stotinu predavanja iz glazbenoga odgoja i etnomuzikologije na seminarima i znanstvenim skupovima u Zagrebu, Novom Vinodolskom i Ljubljani, u Mađarskoj (Šopron, Koljnof, Bizonj, Nagykanizsa), u SAD-u (New York, Philadelphia, Cleveland, Pittsburgh, Chicago i Milwaukee), u Kanadi (Toronto, Montreal, Hamilton). ${ }^{13}$ Mnogo stručnih, znanstvenih i popularnoznanstvenih radova te vlastitih skladbi objavio je u muzikološkim, pedagoškim i drugim novinama, časopisima, zbornicima i kalendarima. ${ }^{14}$

Motiv neumornoga rada Miroslava Vuka Croate u prikupljanju i bilježenju narodnih popijevaka treba prepoznati u želji da »učvrsti i širi zajedništvo $u$ hrvatskom narodu $\ll^{15}$ Vidljivo je to $\mathrm{u}$ svim predgovorima njegovih pjesmarica, kao i u njegovoj opsežnoj pisanoj ostavštini - korespondenciji s osobama u Hrvatskoj i dijaspori. U pismu prijatelju Zvonku Bartoliću, koji je od njega bio zatražio neke podatke o međimurskom kantoru Florijanu Andrašecu 1988. godine, Vuk Croata piše:

»Celi jen dan sam potrošil na prekapanju svoje, bumo rekli, arhive i konstanteral sam da imam se skup, kaj ja nekomu, kaj drugi mej, ravno 5312 (pet jezer tristo i dvanajst) pismi, dopisnici i razglednici (a ober dve jezere čestitki za Božić, Novo leto, Vuzem sam podelil eli fkraj hitil).«16

U tome smislu je izuzetno važan rad Vuka Croate na onim područjima u kojima žive Hrvati u dijaspori u srednjoj Europi, osobito na područjima gradišćanskih Hrvata. ${ }^{17}$

\footnotetext{
${ }^{12}$ M. VUK, Biografija akademika Vinka Žganca, u: Hrvatske pučke popijevke iz Medimurja, knj. 1, za tisak priredio Jerko Bezić i dr., Zagreb 1990; M. VUK, Miroslav Magdalenić, najizvorniji skladatelj Međimurja. Uz osamdeset i petu obljetnicu rođenja, Kaj, 24 (1991) 5-6, 57-74; M. VUK, Prešućeni skladatelj Mirko Kolarić. U povodu 80. obljetnice rođenja i 45. obljetnice tragične smrti, Kaj, 24 (1991) 2-3, 63-72.

${ }^{13}$ Usp. Razum, Miroslav Vuk Croata..., 570.

${ }^{14}$ Vuk je surađivao i u mnogim časopisima: »Modra lasta (1961-1963, 1976-1978, 1981-1983, 1985, 1987), »Muzika« (1976), »Školske novine« (1976-1979, 1984, 1991), »Sveta Cecilija « (1977, 1983-1987, 1989-1998), »Marulić« (1981, 1986), »Radost« (1982-1983), »Suvremena metodika nastave hrvatskog jezika « $(1982,1984), » \operatorname{Kaj} «(1991,1995)$, »Međimurje«, »Hrvatski kajkavski kolendar« (1993-1999, 1994-2000), »Narodna umjetnost« (usp. isto).

${ }^{15} \mathrm{KKBF}$ : fasc. - MVC Korespondencija.

${ }^{16}$ Isto.

${ }^{17}$ Usp. Josip ŠIMUNKO, Kapitalno djelo Miroslava Vuka Croate, Međimurske novine, 18. travnja 2001., 4.
} 


\section{Motiv, način i metode djelovanja Vuka Croate,}

Način i metodu djelovanja Vuka Croate prepoznajemo u njegovim vlastitim riječima izgovorenima članovima Hrvatskoga seljačkog pjevačkog društva »Podgorac« u Gračanima u Zagrebu 24. ožujka 1990. godine:

»Naši časni preci, unatoč teškom i mukotrpnom životu ratara i težaka, radovali su se u pjesmi i kroz stoljeća stvarali i stvorili neprocjenljiva djela na području narodnog stvaralaštva i time pokazali i dokazali da su narod od imena i ljudi od povijesti. Sveta je dužnost sviju nas da ovu stoljetnu stvaralačku nit ne prekinemo nego da je sačuvanu obogatimo novim nacionalno-umjetničkim sadržajima i takvu predamo našim potomcima koji će doći i naslijediti nas. Kad nas bilo nije, pjevala se naša pjesma, i kad nas biti neće, ona će se i nadalje pjevati, i svi mi koji na bilo koji način njegujemo tu našu pjesmu, iako nas više neće biti među živima, ipak ćemo živjeti u toj našoj pjesmi. «18

Vuk Croata se radovao svakom pismu u kojemu bi mu stigla koja nova popijevka ili »viža« (napjev). Tako primjerice prijatelju Ivanu Kozjaku iz Belice piše:

»Vi niti ne znate koliko ste me ugodno iznenadili i razveselili, a to je bilo tuliko kaj sem zastavio poštara i skupa ž nim si spil malo žganice Vama, dragi Ivane u čast i zdravlje, a on me pita: Je pa kaj je bilo vu tem pismu kaj ste tak vesel postali? Ja sam mu povedal, a on je samo uzdahnuo. Jadni ljudi koji dođu vama u ruke, nikad nikome ne date mira, sam Vam moraju uvijek nešto pisati i slati! I nastavio je: Pak sam Vam več ja donio najmanje hiljadu pisama i uvijek netko šalje nekakve pjesme i viže... (20. listopada 1981.). «19

Način prikupljanja crkvenih napjeva, unatrag pedesetak godina (u razdoblju od 1946. do 1992. godine) diljem srednje Europe u mjestima gdje žive Hrvati, Vuk Croata opisuje u predgovorima i pogovorima svojih pjesmarica, a na jednom mjestu ovako:

»Napjevi i riječi bilježene su u toku samog hodočašća u Mariji Bistrici, u crkvi Majke Božje Vinske, u franjevačkim crkvama u Čakovcu i Varaždinu i na Trsatu, zatim u hrvatskom Gradišću u Koljnofu, u Celju i Juru. Pojedini stariji orguljaši i vižari (započimatelji), odnosno vižarice (započimateljice) pjevali su mi u svojim domovima. ${ }^{20}$

Glavni pomoćnici u bilježenju, a poslije i u snimanju, bili su mu orguljaši (školniki, kantori) ili župnici, odnosno stariji pjevački voditelji pjevanja u pojedinim crkvama gdje nije bilo orguljaša. ${ }^{21}$ Posebnu je pozornost posvetio muzikološkim istraživanjima o gradišćanskim Hrvatima. Tako je u pismu Đuri Frankoviću u Pečuh 16. veljače 2004. godine napisao:

\footnotetext{
${ }^{18} \mathrm{KKBF}$ : fasc. - MVC Znanstveni skupovi.

${ }^{19} \mathrm{KKBF}$ : fasc. - MVC Korespondencija.

${ }^{20}$ M. VUK, Hrvatske romarske popijevke, Zagreb, HKD Sv. Jeronima, 1996, 147.

${ }^{21}$ Usp. isto.
} 
»U SAD-u sam boravio kao glazbenik, ali kad sam vidio kako naši ljudi u Americi skoro i ne znaju o gradišćanskim Hrvatima ono najosnovnije, to sam u toku dva mjeseca održao dvadesetak predavanja o Gradišću i našima u njemu. Kasnije sam sve rečeno zabilježio u jednu cjelinu, umnožio desetak primjeraka, a sad jedan primjerak šaljem i Vama, zaista na brzinu. Vi vidite može li Vam gdje koristiti. Sadržaj nije dosada nigdje objavljen. « $^{22}$

U pismu misionaru u Australiji fra Klementu Vladi Novaku, profesoru, orguljašu i zborovođi, članu Hrvatske franjevačke provincije sv. Ćirila i Metoda u Zagrebu, Vuk Croata 8. travnja 1990. godine piše o pjesmarici »Jačke gradišćanskih Hrvata u Mađarskoj« i kaže mu da se gotovo punih 13 godina mučio s njom: »No, sad sam našima napravio ono što im nije nitko unatrag 450 godina.... $\aleph^{23}$ Tome valja nadodati i podatak da je sve to Vuk Croata činio o vlastitom trošku, bez ikakve materijalne podrške.

U ovom se radu valja izdvojeno osvrnuti na poseban angažman Vuka Croate: na promidžbi glazbene kulture gradišćanskih Hrvata te u čuvanju kajkavske kulturne baštine na »Danima kajkavske riječi u Zlataru« - tj. na znanstvenim skupovima o kajkavskom narječju i književnosti. ${ }^{24}$

\section{Etnomuzikološki prinosi Miroslava Vuka Croate}

\subsection{Miroslav Vuk Croata - etnomuzikolog hrvatskoga Gradišća}

Zanimljiv je rad Vuka Croate na prikupljanju jezično-glazbene crkvene i svjetovne glazbene baštine gradišćanskih Hrvata, osobito u mađarskom dijelu hrvatskoga Gradišća. Velika zauzetost u čuvanju glazbene tradicije gradišćanskih Hrvata vidljiva je iz njegove korespondencije sa svećenikom Pavlom Horvatom $^{25}$ iz Koljnofa kojega je upoznao za vrijeme »Hrvatskoga proljeća« 1971. godine. Objavio je njegov nabožni kanconijer od pedeset pjesama nazvavši ga »Molitve« (Sopronkövesd, 1987). ${ }^{26}$

Vuk Croata je zamolio vlč. Horvata da pobilježi popijevke koje pjevaju njegovi vjernici. U prikupljanje su se uključili i župnik u Pinkovcu, Ferdo Sinković te Vilma Grafleiter iz Bizonje. Plodovi toga rada vidljivi se u objavljenoj pjesmarici (jačkaru) »Jačke gradišćanskih Hrvata u Mađarskoj« tiskanoj u nakladi budimpeštanskoga Saveza Hrvata u Mađarskoj 1991. godine, kao i u zbirkama

\footnotetext{
${ }^{22}$ KKBF: fasc. - MVC Korespondencija.

${ }^{23}$ Isto.

${ }^{24}$ Usp. Barbara MATEJČIĆ, Propitivanje kajkavštine, Vjesnik, 27. travnja 1998., 9.

${ }^{25}$ Pavao Horvat (Horvath) (Vedešin, mađ. Hidegség, 1930. - Sopronkövesd, 2009.) je svećenik, hrvatski pjesnik i romanopisac za djecu iz mađarskog dijela Gradišća. Pripadnik je gradišćanskih Hrvata. Pisao pjesme na narječju svog sela Vedešina.

${ }^{26}$ Pavao HORVAT, Molitve, ur. M. Vuk, Zagreb, 2000.
} 
crkvenih pjesmarica »Hrvatske romarske popijevke«, »Hrvatske božićnice« i »Hrvatske uskrsnice«.

O poteškoćama oko tiskanja ove pjesmarice u pismu Petru Tyranu, Željezno (16. srpnja 1988.) Vuk Croata piše:

»Eto za tisak, izdavanje zbirke se materijalna pomoć u našoj jadnoj Yugi ne može očekivati. Bio sam i u Institutu za proučavanje folklora SRH, međutim tamo su ljudi negativno reagirali na moj rad i namjeru da se zapisi objave, jer oni imaju svoje poglede na svijet, na sadašnji položaj, kako oni kažu, naših manjina izvan Jugoslavije i čak su od mene tražili da izbacim neke jačke gdje se spominje, Hrvat i hrvatstvo. Kad sam to čuo, poslao sam ih dovraga i otišao. Međutim ostavio sam Vama i gosp. Pavlu Horvatu: Maticu iseljenika i Društvo za suradnju s gradišćanskim Hrvatima u Zagrebu. Od njih bi se moglo nešto očekivati kao i od Društva književnika Hrvatske kojeg ste i Vi član. Zar ne? (Ja sam inače ovdje proglašen za crnu ovcu!!!) Samo kod tih biste morali pismeno tražiti uz predočenje recenzija. « ${ }^{27}$

Budući da su »Jačke gradišćanskih Hrvata u Mađarskoj« tiskane u Budimpešti 1991. godine, Vuk se odrekao honorara te u tom kontekstu piše:

»Odričem se honorara u korist hrvatskoga kluba u Koljnofu - ovlašćujem gospodina predsjednika Pajrića da umjesto mene primi honorar za spomenutu knjigu u korist spomenutoga kluba. $\aleph^{28}$

Ta zbirka, jednostavno nazvana »Jačkar« (Pjesmarica), sadrži dio onoga što je Vuk uspio prikupiti prigodom mnogih posjeta hrvatskim selima oko Šoprona i uz današnju granicu Mađarske s Austrijom. A kako je taj posao bio težak i mukotrpan (Vuk je bio čak u mađarskom zatvoru!) pokazuje činjenica da je za svoja putovanja morao imati različita dopuštenja i odobrenja, a do tamošnjih sunarodnjaka morao se probijati kroz nevjerojatan sustav straža, kontrola i drugih oblika potpune izolacije kojima su bili dugo i donedavno okruženi. Stoga se teško oteti dojmu da je upravo ta i takva izolacija tih Hrvata pridonijela očuvanju zanimljive izvornosti i osebujnosti njihova jezika, pjesništva i glazbe. U »Jačkaru« su prikupljena 264 naslova raznih jački (pjesama) iz hrvatskih mjesta u Mađarskoj: Bizonja, Narda, Hrvatski Židan, Temerje, Koljnof, Vedešin, Kemija, Petrovo Selo, Prisika, Hrvatske Šice, Umok, Plajgor i Gornji Čatar. Tu je prvi put, od druge polovice 16. stoljeća pa do danas, objavljeno 230 naslova (dakle, $86 \%$ ); dok su ostala 34 naslova bila objavljena prije u raznim zbornicima (tek 12,6\%).

Poznato je da su narodne pjesme gradišćanskih Hrvata prikupljali, proučavali i objavljivali u svoje vrijeme i Fran Kurelac, Franjo Kuhač, Matija Meršić te Vinko Žganec. Manje je pak poznato da su se svi oni bavili narodnom umjetnošću austrijskoga dijela Gradišća, dok su gradišćanski Hrvati u Mađarskoj - a nije ih malo - dugo ostali izvan zanimanja znanstvenih krugova. Razlog tome

\footnotetext{
${ }^{27}$ KKBF: fasc. - MVC Korespondencija.

${ }^{28}$ Isto.
} 
bile su uglavnom političke okolnosti, osobito mađarska asimilatorska politika! Ozbiljnije se na njih osvrnuo samo Tihomir Vujičić u zbirci notnih zapisa i stihova »Muzička tradicija Južnih Slovena u Mađarskoj«, izdanoj 1978. godine u Budimpešti, a u koje je uvršteno 9 jački koje je prikupio. ${ }^{29}$ Tako je, prema Vuku Croati, Fran Kurelac oko 1871. godine prikupio 10 jački; Franjo Kuhač od 1878. do 1881. godine 10 jački; Meršić - Žganec 1964. godine - 4 jačke. Vuk Croata smatra da je Žganec u Gradišću bio od 31. prosinca 1961. do 2. siječnja 1962. No, za Žganca su građu prikupljali Emil Palić i Tomislav Buljan. Materijal je bio predan u Željezno kanoniku Martinu Meršiću, dok se neke Žgančeve bilješke nalaze $u$ arhivu HAZU-a u Zagrebu. ${ }^{30}$

Zapazili smo da se pjesma »Na placi sam stal« iz »Jačkara« (br. 86, str. 117), također nalazi u četvrtoj knjizi »Pěsme Ivana Kukuljevića Sakcinskoga« s dodatkom »narodnih pěsamah puka harvatskoga«, pod naslovom »Prevareni« iz Čunova. Čini se da ju je Vuk Croata zabilježio u Hrvatskim Šicama i Gornjem Čataru u verziji za dva dvostiha kraćoj od Kukuljevićeve koji je, tvrdi Jembrih, u Požunu (Bratislava/Pressburg) boravio 1835. godine. ${ }^{31}$

»Jačkar« sadrži raznoliku i zanimljivu glazbenu i jezičnu građu. Sve jačke, svrstane su u sedam skupina, a odražavaju ljubav prema svome rodu i hrvatskom Gradišću. Većina je zabilježena u durskim i molskim ljestvicama, a pri tomu je važno napomenuti da sadržaj riječi u jačkama gradišćanskih Hrvata često određuje tonalitet napjeva. Vuk Croata je opazio da je melodijsko kretanje tonova u gradišćanskim jačkama vrlo slično kretanju tonova u međimurskim popijevkama, ${ }^{32}$ kao i šire - do Dalmacije, ${ }^{33}$ tj. s hrvatskim pučkim napjevima općenito. Međutim, u jačkama nalazimo i melodijske pomake s osobinama germanske glazbe koja je stoljećima utjecala na gradišćansku pučku popijevku (primjerice, »Sal se ženit Marko mlad«, br. 23, str. 45).

U prikupljenim su jačkama prisutne mješovite mjere (primjerice, »Izvan briga stugivala«, br. 59, str. 83 - mjere u jački 6/8, 9/8, 4+8/8, 3+9/8 itd.). Posebna ritamsko-melodijska obilježja vidljiva su u jački »Kiša pada«, br. 150, str. $197 \mathrm{i} \mathrm{u}$ sinkopama u jački »Curi tiha godinica«, br. 148, str. 195).

\footnotetext{
${ }^{29}$ Tihomir Vujičić, srpski skladatelj i etnomuzikolog u Budimpešti, rođen je 23. veljače 1923. u Pomazu u Mađarskoj, a poginuo je u zrakoplovnoj nesreći 19. kolovoza 1975. u Damasku u Siriji. Prvu zbirku narodnih pjesama objavio je 1959. godine pod naslovom »Naše pesme«, a rezultati njegova prikupljanja poslije toga objavljeni su posthumno [usp. Petar LASTIĆ, Tihomir Vujičić (1923-1975), (03.02.2011), www.riznicasrpska.net/muzika/index.php?topic=108.0; (02.01.2018)].

${ }^{30} \mathrm{KKBF}$ : fasc. - MVC Znanstveni skupovi.

${ }^{31}$ Usp. Alojz JEMBRIH, Jačke gradišćanskih Hrvata u Kukuljevićevoj zbirci pjesama iz 1847. godine, u: B. FILIPAN (ur.), Kukuljevićevi dani u Varaždinskim Toplicama. Zbornik radova znanstveno-stručnih skupova Matice hrvatske 2001.-2003., Varaždinske Toplice, Ogranak Matice hrvatske, 2004, 344-353.

${ }^{32}$ Gotovo četvrtina jačka u »Jačkaru« u svojim napjevima ili tekstovima ima više ili manje naglašeno zajedništvo s međimurskim pučkim popijevkama.

${ }^{33}$ Primjerice, jačka »Prik noći«, br. 249, str. 329.
} 
Moguće je također uočiti vrlo veliku sličnost teksta »Jačke od mladenca«, posljednje u »Jačkaru« (br. 264, str. 346), čiji je autor riječi i melodije Juro Vajković (»Poslušaite rieči jednoga mladenca, jer v svojem betegu zdihava prez konca«), s popijevkom »De agonizante peccatore« (»O umirućem grešniku« iz Pavlinske pjesmarice /»Poslušajte, bratja, čudna dogovanja od grešna človeka kaj se je zgodilo jedno pervo vreme, za negdašnih ludi...«/). ${ }^{34}$

»Jačkar«, uz folklorističke i glazbene vrijednosti, ima i posebne književne i jezične značajke, izražene najvećim dijelom uporabom hibridnoga hrvatskoga jezika (mješavine čakavskoga, kajkavskoga i štokavskoga narječja). Vuk Croata smatra da se upravo popijevkom najlakše može doći do znanstvene istine o pravilnosti izgovora bilo koje riječi ili govora, jer pjevač u pjevanju nema vremena improvizirati. Zato »Jačkar« književnoj znanosti nudi »obilje građe za proučavanje lirske poezije, a dijalektologiji daje podatke o fonologiji, stilistici i leksiku gradišćanskih Hrvata ${ }^{35}$

Poznato je da su se $\mathrm{u}$ hrvatskom Gradišću javljala kolebanja u izgovoru afrikata $c$ i $c$ te diftonga oa, ie, ae. ${ }^{36}$ Vuk Croata je uz to nailazio i na više jezičnih, melodijskih i ritamskih inačica, te isticao da se uvijek odlučio za najučestaliji jezični izraz i izgovor i za najučestaliju melodijsku i ritamsku inačicu, poštujući njihov sadašnji tekstualni i melodijski oblik. ${ }^{37}$ Valja spomenuti da je u bilježenjima i istraživanjima zapazio da neke pučke popijevke u glazbenoj obradi i inačicama nisu tako zabilježene u etnomuzikološkoj literaturi.

Posebnu važnost $u$ istraživanjima Vuka Croate zadobio je Juro Vajković, ${ }^{38}$ kantor-učitelj rodom iz Trajštofa, za kojega je utvrdio da se u Gradišću nije ni znalo za njega. Istražujući razloge otkrio je da se u Austriji i Mađarskoj za Vajkovića nije ni moglo znati jer se u njih pjevaju samo dvije njegove pjesme, a i te dvije bez imena autora. U hrvatskoj crkvenoj popijevci je pak više od stotinu godina vođen pod pogrešnim imenom kao Đuro Veljković ili Vejković. ${ }^{39}$ Juro

${ }^{34}$ Pavlinski zbornik, Zagreb, HAZU, 1991, 210; faksimil Pavlinskoga zbornika, s Pavlinskom pjesmaricom, transkripcija tekstova i znanstvenih studija Vladimir Zagorac, Antun Šojat i Koraljka Kos.

${ }^{35}$ Usp. Franjo DAMIŠ, Ljubav prema rodu. Nova hrvatska pjesmarica u Mađarskoj »Jačke gradišćanskih Hrvata«, Glasnik, 23. studenoga 1992., 40.

${ }^{36}$ Autori i njihove bibliografske jedinice koje se bave jezikoslovnim problemima izgovora artifikata: Andrea Zorka KINDA-BERLAKOVICH, Razlike u čakavskim ikavsko-ekavskim govorima srednjega Gradišća, Hrvatski dijalektološki zbornik, 21 (2017) 163-176; Sanja VULIĆ, Tvorba riči Gramatika gradišćanskohrvatskoga jezika, Ivo Sučić (ur.), Željezno, Znanstveni institut Gradišćanskih Hrvatov, 2003, 245-390; Sanja VULIĆ, Prilog utvrđivanju govorne osnovice rukopisnog gradišćanskohrvatskog rječnika Pannonisches Jahrbuch (Panonska ljetna knjiga), Robert Hajszan (ur.), Güttenbach/Pinkovac, Pannonisches Institut - Panonski institut, 2 (2000) 447-45; Sanja VULIĆ, Štokavski elementi u govoru čakavskoga gradišćanskohrvatskoga sela Pinkovca, Panonski ljetopis / Pannonisches Jahrbuch, Robert Hajszan (ur.), 1995, 268-273.

${ }^{37}$ Usp. Vuk, Hrvatske božićnice..., III.

${ }^{38}$ Usp. Janko BARLÈ, Nešto o crkvenim jačkama ugarskih Hrvata, Sv. Cecilija, 5 (1917) 149-156, 156.

${ }^{39}$ Usp. M. VUK, Juro Vajković nije Đuro Veljković ili Vejković, Sv. Cecilija, 2 (1993) 28-29. 
Vajković je kao nadaren mladić od 14 godina bio postavljen za "preceptora«, pomoćnoga učitelja, tj. učiteljskoga inuša u rodnom Trajštofu (1813-1814), a potom je radio u Bizonji (1815-1818, 1825-1828) i u Pandrofu (1818-1822). Umro je 29. rujna 1875. u Trajštofu. ${ }^{40}$

»O pok. Vejkoviću piše nam prijatelj: 'Iz Bizonje je došao za školnika u Szentelek (Stegersbach, na štajerskoj granici; pol sela Hrvati, pol Niemci). Bio je glasovit jačkar, još ga danas spomenjuju stari ljudi. Povidalo se je onda, da je bio potvoren, kot da bi kroz njegovu krivicu nastao požar na seli Szentelek, a to da mu je glavu za vas život pomutilo. Bio je pod starost do smrti velika, velika sirota. Ja sam ga kot studenat (1864.-1874.) dostakrat vidio i - Bog mi oprosti! - podražio, nego imena mu nisam znao, ar mi mladi vetrenjaki smo ga zvali imenom, ko si je sam dao: legitimus (recte legatus) Dei. Sada se spominam, da je od sela do sela na 2-3 dni pohadjao školnike, pri njih zadržavo, dokle ga nisu dalje poslali. Kad je vino pio, je čašu blagoslovio ter rekao: supra hunc calicem. Tako je imao sebe i na papiru naslikano. Po tielu bio je sridnje višine, rumeno lice, snažan starac, žalosan pogled, još sada kot da ga vidim. Kade, va kom selu ga je dosegla smrt, to sam znao, ali sada pod starost zabio. «11

Vajković je, otkriva Vuk Corata, kao skladatelj-orguljaš bio prvi koji je prikupljao jačke i prvi koji je uz tekst zapisao i melodije i tako ostavio pravo biserje svoga rada i uma. Njegove je pjesmarice, čini se, Mate Meršić-Miloradić poslao u Zagreb kanoniku Janku Barlèu koji je zapisao da one »sadrže puno lijepih starih hrvatskih popijevki koje su Hrvati vjerojatno ponijeli iz svoje stare domovine, barem veći dio «. ${ }^{42}$

Valja zamijetiti da su Janko Barlè i njegov suradnik Franjo Dugan, skladatelj, orguljaš, glazbeni pedagog, dirigent, pisac brojnih glazbenih članaka i kritika te urednik i glazbenoga priloga »Sv. Cecilije«, nastojali zajedničkim radom na Vajkovićevim pjesmaricama i glazbenim analizama oživjeti sve one stare popijevke za koje su smatrali da su hrvatske, a koje su se sačuvale u hrvatskoj dijaspori ili su ih Hrvati ponijeli iz svoje stare domovine. Neke od tih općepoznatih popijevaka su: »Rodio se Bog i čovjek«, »O, pastiri, vjerni čuvari«, »Kada zvijezda divna«, zatim u čast Blažene Djevice Marije »K tebi oči podižemo«, »Zdravo budi, Kraljice«, »Marijo, slatko ime« i »Marijo, pogledaj s visina«. Raščlambom pojedinih crkvenih i svjetovnih pjesama, Miroslav Vuk Croata dokazuje

»da su Hrvati u Gradišću, Slovačkoj i Moravskoj, unatoč granicama koje su ih dijelile od matične Hrvatske, oduvijek činili jedinstven hrvatski kulturni i vjerski korpus i da su mnoge popijevke iz hrvatske dijaspore stoljećima putovale u staru domovinu, gdje su se zadržale do danas, ali i da su mnoge crkvene popijevke iz hrvatskih, napose kajkavskih, krajeva isto tako kulturno i duhovno obogaćivale crkveno blago Hrvata u iseljeništvu«. ${ }^{43}$

\footnotetext{
${ }^{40}$ Usp. Stefan KOCSIS, Zur sakralen Musik der Burgenländischen Kroaten in Geschichte und Gegenwart. »...und sie singen noch immer«, Željezno, HKDC, 1998, 242.

${ }^{41}$ Usp. Barlè, Nešto o crkvenim jačkama..., 189.

${ }^{42}$ Usp. isto, 187.

${ }^{43}$ Usp. J. KOLARIĆ, Hrvatske uskrsnice, Zagreb, Naklada »Dr. Feletar«, 1998, ix.
} 


\subsection{Miroslav Vuk Croata i kajkavska kulturna narodna baština}

Uz folkolorističke i muzikološke odlike, Vuk Croata je zamijetio da hrvatska bogata glazbena baština, nedvojbeno, ima i svoje književne, jezikoslovne i druge vrijednosti. Kao što je poštivao autentičnost pučke popijevke na razini napjeva pojedine glazbene eksplikacije (trudio se također da harmonizacije popijevaka odgovaraju stilu popijevke i vremenu u kojem je pojedina popijevka nastala te pučkom načinu orguljanja!), podjednako je to činio i na razini njezina jezičnoga predloška. U svojim pjesmaricama Vuk Croata ima konkretnu namjenu: svratiti pozornost na dio stare hrvatske crkvene tekstovne i glazbene baštine pretežno iz minulih stoljeća: u prvom redu s kajkavskih jezičnih područja u sjevernoj Hrvatskoj, a isto tako i u dijaspori, s nakanom »za korištenje hrvatskom vjerničkom puku u crkvi i izvan nje $\ll^{44}$ Stoga Joža Skok s pravom Vukovu pjesmaricu »Hrvatske božićnice« naslovljuje »Traganja za praizvorima hrvatske riječi i glazbe ${ }^{45}$ Knjige-pjesmarice Miroslava Vuka Croate nisu, dakle, samo dokument o glazbenoj kulturi Hrvata nego i jak dokaz stalne lingvističke činjenice, a to je povezanost hrvatskih narječja i međunarječnih utjecaja. ${ }^{46}$

Osim toga, pjesma, njezin sadržaj i napjev - osobito crkvena popijevka često izražavaju specifičnu ćud, život i običaje božićnoga, korizmenoga i uskrsnoga vremena, kao i u vrijeme hodočašćenja hrvatskoga naroda. S glazbenoga gledišta popijevke potvrđuju duboku povezanost s etno-glazbom hrvatskoga naroda, kao i prisutnost gregorijanske melodijsko-ritamske estetike i karakteristične dijatonike. Vuk Croata otkriva povijest postanka svake popijevke, njezina širenja i života u vremenu i prostoru. Ističe da su se mnoge popijevke do 1960-ih pjevale po svim župama sjeverne Hrvatske:

»Prelistavanjem molitvenika tiskanih u 18. i 19 stoljeću, posebno onih koji su tiskani u Beču, Trnavi, Šopronu i Juru, dolazi se do spoznaje da sve popijevke koje su pjevali, a i danas pjevaju međimurski romari nisu izvorno međimurske. Nekima je autor teksta isusovac Juraj Mulih ili franjevac Lovro Bogović, a mnogima pak hrvatski narod - od Senja, Novoga Vinodolskoga, Požege i sve u hrvatskom Gradišću do Bizonje i Hrvatske Kemlje u današnjoj Mađarskoj.«77

Tako o atribuciji pojedinih napjeva isusovcu o. Juraju Mulihu Vuk Croata piše:

»Na temelju više nego dvadesetogodišnjega proučavanja raznih starih hrvatskih pjesmarica i molitvenika kao i dostupnih podataka o njegovu životu i radu možemo sa sigurnošću kazati da je o. Juraj Mulih autor tekstova popijevaka 'Kraljice nebeska', zatim popijevke od sv. Ivana Nepomuka 'Poslušajte, ljudi, kak žene, tak muži' i današnje korizmene 'Ja se kajem, Bože mili'««8

\footnotetext{
${ }^{44}$ KKBF: fasc. - MVC Korespondencija.

${ }^{45}$ Usp. Vuk, Hrvatske božićnice..., X-XI.

${ }^{46}$ Usp. Joža SKOK, Traganja za praizvorima hrvatske riječi i glazbe, u: Vuk, Hrvatske božićnice..., $\mathrm{X}$-XI.

${ }^{47}$ M. VUK, Pogovor, u: isti, Hrvatske božićnice..., 148.

${ }^{48}$ Isto, 161.
} 
Raščlambom pojedinih pjesama Vuk Croata je došao do spoznaje da su međimurski pjevači (kantori, školniki) poznavali sva tri izdanja poznate zbirke popijevaka »Cithara octochorda $^{49}$ i njima se služili. ${ }^{50} \mathrm{~S}$ obzirom na stvaranje »Cithare octochorde« Vuk Croata kaže:

»Sa sigurnošću možemo kazati da je prečasni zagrebački kanonik Toma Kovačević za vrijeme svoga boravka u Beču koncem 17. stoljeća posjetio i naše Hrvate u Gradišću i tamo zabilježio više popijevaka, od kojih su mnoge uvrštene i u 'Citharu', ${ }^{51}$

Vuk Croata je sudjelovao i na znanstvenim skupovima o kajkavskom narječju i književnosti, osobito na znanstvenim skupovima o kajkavskom narječju i književnosti »Dani kajkavske riječi u Zlataru«. Pokrenuti su 1970. godine, a održavali su se u gradskoj vijećnici pod pokroviteljstvom Vjesnika do 1976. godine, kada su na zahtjev tadašnjih lokalnih vlasti ukinuti zbog, za njih, nepodobnoga sadržaja referata. Od 1992. godine opet se redovito održavaju svake druge godine pod pokroviteljstvom Razreda za filološke znanosti i Razreda za suvremenu književnost HAZU-a. Ugledni hrvatski znanstvenici, jezikoslovci i književni povjesničari, pod presjedanjem Stjepka Težaka, Ivana Sovića i Josipa Šimunca, održali su književna i jezikoslovna predavanja o kajkavskom narječju. Tako je i Vuk Croata 18. rujna 1992. na znanstvenom skupu o kajkavštini zorno, pjevajući i čitajući kajkavske melodije i tekstove, dočarao djelo skladatelja Ivana Mustača, međimurskoga orguljaša, dirigenta i skladatelja. ${ }^{52}$

U Vuka Croate posebno je zanimanje pobuđivala tzv. međimurska kajkavština koja je bila u uporabi u crkvenim popijevkama i to u starijih osoba. $\mathrm{Na}$ znanstvenom skupu u Zlataru 22. rujna 1996. godine predstavio je pjesmaricu »Hrvatske romarske popijevke« i svoj način bilježenja popijevaka:

»Pri uređivanju pojedine popijevke i čitave zbirke uvijek sam se odlučio za najučestaliji jezični izraz i izgovor i za najučestaliju melodijsku i ritamsku inačicu. Kod pojedinih popijevaka zabilježio sam i do tridesetak inačica. Karakteristične izgovore pojedinih slogova (vokala) u pojedinim riječima obilježio sam naglascima (akcentima) koji se izgovaraju á = dugouzlazno, zatvoreno kao: já, ná, pák itd.; $\hat{e}$ = dugosilazno, zatvoreno kao: nê, tê, pêh itd.; ô = dugosilazno, zatvoreno kao: tô, bô, rôn itd. Pjevači su u pojedinim popijevkama različito izgovarali iste riječi. Na primjer: bili, molili, premislite, odnosno: bilji, molilji, premisljite itd. Naime, kada se u hrvatskom kajkavskom govoru donjega Međimurja javlja 'e' ili 'i' iza suglasnika 'l', taj se 'l' umekšava, palatalizira. Na nekim mjestima suglasnik 'l' se palatalizira i ispred samoglasnika 'u'. Na primjer: 'smiluj' = gornje

\footnotetext{
${ }^{49}$ »Cithara octochorda« je najpoznatiji i najopsežniji stariji hrvatski tiskani zbornik crkvenih pjesama na latinskome i hrvatskome jeziku. Objavljen je u tri izdanja: u Beču $(1701,1723)$ i Zagrebu (1757). Pretpostavlja se da je prva dva izdanja priredio zagrebački kanonik Toma Kovačević, a treće Mihael Šilobod-Bolšić.

${ }^{50}$ Vuk, Pogovor, u: isti, Hrvatske božićnice..., 150.

${ }^{51}$ Isto, 163.

${ }^{52}$ Usp. S. TEŽAK, Oživljeni znanstveni skup o kajkavštini, Školske novine, 29. rujna 1992., 12.
} 
Međimurje, 'smiljuj' = okolica Kotoribe, ili 'sluga - sluge' i 'sljuga - sljuge' = donje Međimurje. $\ll^{53}$

Prema tvrdnjama Vuka Croate u Međimurju postoje »štiri kajkavska pučka, narodna govora po dijački 'narječja', i to ker meje s deželom, okouli Murskoga Središća, okoli Kotoribe, majčko Dekanovec i okolica Čakovca«. ${ }^{54}$

Vuk Corata je na »Danima kajkavske riječi u Zlataru« 25. travnja 1998. održao predavanje na kajkavštini o svojoj knjizi-pjesmarici »Hrvatske uskrsnice« otpjevavši i poneku tradicionalnu kajkavsku pjesmu. Time je, osim lingvističke, pokazao i glazbenu važnost kajkavštine. ${ }^{55}$

U Krapini je 1999. godine govorio o međimurskom pjesniku skladatelju Florijanu Andrašecu i njegovim pjesmama:

»Kao pjesnik Florijan je pisao lirske stihove i sve njegove pjesme, odnosno njihovi sadržaji, mogli bi se nazvati lirskom kronikom Međimurja prije Prvoga svjetskog rata, za Prvoga svjetskog rata i između dva svjetska rata.« ${ }^{56}$

Zapazio je da Andrašecove pjesme imaju svojevrsnu dijalektološku vrijednost jer je pretežno zastupljena međimurska kajkavština novijega vremena, ali i tragovi hrvatskoga književnoga jezika, kao i poneka slovenska riječ.

U Zlataru je 2000. godine održao referat o rukopisnoj školničkoj pjesmarici braće Kollay s početka 19. stoljeća. Detaljnim je istraživanjem Vuk Croata došao do podatka da je najpoznatija i najpjevanija božićna popijevka »Kyrie eleison« nastala u krugu obitelji Kollay u Međimurju između 1820. i 1835. godine. Autorom teksta smatra kotoripskoga orguljaša Janka (Januša) Kollaya (s kraja 18. stoljeća ili prve polovice 19. stoljeća), a čini mu se da su rad na njoj dalje nastavili njegovi sinovi Hieronim i Ambroz. Ambroz je popijevku uvrstio i u svoju rukopisnu pjesmaricu »Popevke Bosichne Ambrosiussa Kollay« 1835. godine. ${ }^{57}$ Ta pjesmarica je za hrvatsku dijalektologiju i povijest jezika, posebice u Međimurju, Pomurju i dijelu Podravine, pa i za književnost uopće, vrijedan jezični spomenik. ${ }^{58}$

\section{Zaključak}

Miroslav Vuk Croata nastavio je djelo najpoznatijih međimurskih melografa i etnomuzikologa. Skupljanjem i analizama oživio je sve one stare popijevke za koje je smatrao da su hrvatske, a koje su se sačuvale u hrvatskoj dijaspori ili su ih Hrvati ponijeli iz svoje stare domovine. Svojim višegodišnjim marljivim i su-

\footnotetext{
${ }^{53} \mathrm{KKBF}$ : fasc. - MVC Znanstveni skupovi.

${ }^{54}$ Isto.

${ }^{55}$ Usp. Matejčić, Propitivanje kajkavštine..., 9.

${ }^{56} \mathrm{KKBF}$ : fasc. - MVC Znanstveni skupovi.

${ }^{57}$ Usp. isto.

${ }^{58}$ Usp. Matejčić, Propitivanje kajkavštine..., 9.
} 
stavnim radom, dao je hvalevrijedan doprinos hrvatskoj kulturi, osobito onome dijelu koji se odnosi na glazbenu, folklornu, književnu i inu baštinu ogranka hrvatskoga naroda u Gradišću. Zbog toga je već za života sam sebi postavio trajan i nerazoriv spomenik, a budućim naraštajima ostavio obvezu da nastave tamo gdje je on stao. ${ }^{59} \mathrm{U}$ ovoj studiji nastojali smo prikazati Vukov način prikupljanja građe i motiv, a osobito metodu njegova djelovanja u promidžbi glazbene kulture gradišćanskih Hrvata te u čuvanju kajkavske kulturne baštine. Pritom smo se oslonili na njegove neobjavljene autobiografske bilješke, mnogobrojnu korespondenciju, te drugu zanimljivu građu koja, nažalost, čeka prikladno katalogiziranje i dostupnost istraživačkom korpusu. Knjige-pjesmarice Miroslava Vuka Croate nisu samo dokument o glazbenoj kulturi Hrvata nego i izvor za lingvistička (osobito dijalektološka) i liturgijsko-glazbena istraživanja. Vukova djela značajna su ne samo za kantore i zborovođe, nego i za liturgičare, etnomuzikologe, muzikologe, dijalektologe, jezičare, jezikoslovce i književne kritičare.

Na kraju, valja primijetiti da je Miroslav Vuk Croata objavljivanjem svojih pjesmarica imao sluha i za liturgijsku obnovu, naročito onu koncilsku: »Neka se s najvećom brigom čuva i promiče blago svete glazbe« $\mathrm{i}$ »Neka se njeguje pučko vjersko pjevanje.$^{60}$ Tako je on svojim radom na tom području konkretno odgovorio na poticaje Drugoga vatikanskoga koncila o potrebi čuvanja i promicanja blaga svete glazbe, kao i njegovanja pučkoga pjevanja. Sveta je dužnost sviju nas da ovu stoljetnu stvaralačku nit ne prekinemo nego da je sačuvanu obogatimo novim nacionalnoumjetničkim sadržajima i takvu predamo našim potomcima.

\footnotetext{
${ }^{59}$ Usp. Juraj KOLARIĆ, Miroslav Vuk - Croata, Sv. Cecilija, 4-5 (2005) 8-10; usp. Razum, Miroslav Vuk Croata..., 573-577.

${ }^{60}$ DRUGI VATIKANKI KONCIL, Sacrosantum conciliium. Konstitucija o svetoj liturgiji, (4.XII.1963), u: Dokumenti, Zagreb, Kršćanska sadašnjost, br. 114 i 118.
} 


\section{Katarina Koprek* \\ The contribution of melograph Miroslav Vuk Croata (1930-2005) to Croatian traditional music culture}

\section{Summary}

A great number of Croatian ethnomusicologists from the 20th century include Miroslav Vuk Croata - a collector of the musical treasures of Croatian sacral and secular folklore melodies. As a young collaborator of the famous ethnomusicologist Vinko Žganec, he continued his work: he retained a significant part of the spiritual traditional musical heritage from the forgetfulness - both in Croatia and in the countries where Croats (Austria, Hungary, Slovakia and Moravia) live, collecting, noting down and sound recording sacral and secular folklore melodies. He edited and published the material he had collected during his lifetime. The ethnomusicological talent of Vuk Croatae has become prominent in the musical tales of folk melodies for various choirs of spiritual and secular content. What is particularly valuable is his contribution to the research of folk, secular and ecclesiastical folklore melodies traditionally called (»jački«) from Burgenland Croats. Already from the titles of these melodies the peculiarities of the local speech are noticed. His music anthology confirms the undeniable motive and musical connection of a large number of folklore melodies with related melodies in the homeland, as they reveal some thematic and musical particularities of the new milieu in which Croats live, keeping alive the folklore melody with their old language and old language with the folklore melody, or one with the other, thus preserving its national identity.

Key words: Croatian ethnomusicology, croatology, kajkavian folk heritage, secular and sacral folk melodies, language and culture of Burgenland Croats.

(na engl. prev. Kristina Polegubić)

\footnotetext{
* Katarina Koprek, PhD, Assoc. Prof., Catholic Faculty of Theology, University of Zagreb; Address: Vlaška 38, pp 432, HR-10001 Zagreb, Croatia; E-mail: katarinakoprek@hotmail.com.
} 